\title{
A NEW ARGOCOFFEOPSIS (COFFEEAE, RUBIACEAE) FROM SOUTHERN CAMEROON: ARGOCOFFEOPSIS SPATHULATA
}

\author{
AARON P. DAVIS ${ }^{1} \&$ BONAVENTURE SONKÉ 2,3
}

\begin{abstract}
SUMMARY
A new species of Argocoffeopsis, A. spathulata, is described as new to science. A description, line drawing, distribution map and conservation assessment are provided.
\end{abstract}

Key words: Coffeeae, Argocoffeopsis, Cameroon, plant conservation, IUCN.

\section{INTRODUCTION}

In a recent phylogenetic investigation of tribe Coffeeae (Davis et al. 2007), based on four plastid regions and a morphological dataset, a clade containing the genera Argocoffeopsis Lebrun, Calycosiphonia Pierre ex Robbr. and an entity 'Calycosiphonia cf.' received strong bootstrap support (BP 99) and a high Bremer (decay) value $(b=9)$. Morphologically this clade is distinguished from other Coffeeae by the lack of a readily discernable seed coat (testa). Monophyly was identified for Calycosiphonia (BP 85; $b=3$ ) and Argocoffeopsis (BP 81; $b=2$ ) but Calycosiphonia $\mathrm{cf} .$, based on the sample (Sonké \& Nguembou 3783, K, YA), was placed in an unresolved position at the base of the Argocoffeopsis-Calycosiphonia clade. Data from ITS sequences have not provided further clarification on this matter (A. Davis unpubl. data). These three taxa occur in tropical Africa, with Calycosiphonia $\mathrm{cf}$. being restricted to Cameroon.

Calycosiphonia cf. has all the key characteristics of Coffeeae (Bridson \& Verdcourt 2003, Davis et al. 2007), including the presence of paired, axillary, sessile inflorescences, calyculi (calyx-like cupules at the base of the other inflorescence parts), coffee-like flowers (corolla tube narrow and more or less straight), ovules usually 1 or 2 per locule or up to 10, rarely c. 20 (1 per locule in Calycosiphonia cf.), and a distinctly bilobed stigma. Within the tribe this taxon is very distinct, owing to its large obovoid fruits and leaves with spathulate apices. It is clearly a new species, related to Argocoffeopsis or Calycosiphonia, but with no clear generic affinity.

In general appearance Calycosiphonia cf. looks much more like Calycosiphonia than Argocoffeopsis, owing to its habit (a small, upright, single stemmed tree), with a rather

1) Herbarium, Royal Botanic Gardens, Kew, Richmond, Surrey, TW93AB, United Kingdom; e-mail: a.davis@kew.org.

2) Laboratoire de Botanique systématique et d'Ecologie, Ecole Normale Supérieure, Université de Yaoundé I, B.P. 047, Yaoundé, Cameroon; e-mail: bsonke@uy1.uninet.cm.

3) Laboratoire de Botanique systématique et de Phytosociologie, Université Libre de Bruxelles, Av. F. Roosevelt 50, C.P. 169, 1050 Bruxelles, Belgique; e-mail: bsonke@ulb.ac.be. 
pale and soft peeling ('spongy') shoot bark, which often turns dark brown to blackish on the uppermost parts (as observed on dried herbarium specimens). Calycosiphonia comprises two species, C. macrochlamys (K.Schum.) Robbr., and C. spathicalyx (K.Schum.) Robbr. These taxa can be easily separated from Calycosiphonia cf. because they have obvious anther thecae (absent in Calycosiphonia cf.) and 7- to 8-merous flowers (5-merous in Calycosiphonia cf.). Argocoffeopsis comprises eight species of woody climbers, apart from A. lemblinii (A.Chev.) Robbr. and A. rupestris (Hiern) Robbr., which are shrubs or small trees. Argocoffeopsis does not have anther thecae, and the flowers are 5-8-merous (Robbrecht 1981). Calycosiphonia cf. most closely resembles A. lemblinii, although this species is clearly different. Calycosiphonia cf. has soft peeling ('spongy') shoot bark (when dry), which is glabrous, leaves with spathulate apices, very small to truncate foliar lobes on the upper calyculus ( $0-2 \mathrm{~mm}$ long), 5- (rarely 4-)merous flowers, and a corolla 4.5-6(-10) mm long. Argocoffeopsis lemblinii has smooth shoot bark, which is puberulous, large foliar lobes on the upper calyculus (4-12 mm long), leaves with acute to abruptly acuminate apices, 8-merous flowers, and a corolla 12-15 mm long (Chevalier 1938, Chevalier 17810, P). Calycosiphonia cf. is unlike all other species in either Argocoffeopsis or Calycosiphonia in that the fruits are larger (12-15 mm long) and obovoid. Generally the fruits of Argocoffeopsis and Calycosiphonia are either subglobose, or globose to ellipsoid and less than $10 \mathrm{~mm}$ long.

On basis of all the information given above we hereby take the opportunity to formally describe the entity known as Calycosiphonia cf. (Davis et al. 2007) as a species of Argocoffeopsis: A. spathulata. We see no logic in describing Calycosiphonia cf. in a new genus, as apart from the size and shape of its fruit, it shows no major morphological differences when compared with either Argocoffeopsis or Calycosiphonia. In a scenario that showed Calycosiphonia and Argocoffeopsis to be congeneric, the latter would have priority as it is the earliest published name (Lebrun 1941, Robbrecht 1981).

\section{MATERIALS AND METHODS}

Field collections of A. spathulata were made by B. Sonké \& C. Nguembou, B. Sonké \& Djuikouo, and B. Sonké \& Taedoumg, between January 2005 and June 2006. Duplicates were distributed to BR, BRLU, K, MO, WAG, and YA (abbreviations after Holmgren et al. 1990). Measurements, colours and other details given in the description are based on living material, spirit and herbarium specimens, and data derived from field notes. Herbarium and spirit material was examined using a Leica MZ95 Stereomicroscope. The terminology and descriptive terms and conventions used in this contribution follow those given in Davis et al. (2005, 2007). The conservation status of the new species was assessed by calculating the extent of occurrence and then applying the IUCN Red List Category Criteria (IUCN 2001) using software developed by Willis et al. (2003).

Argocoffeopsis spathulata A.P.Davis \& Sonké, spec. nov. - Fig. 1; Map 1

A. lemblinii (A.Chev.) Robbr. affinis sed ramulis suberosis (nec puberulis), foliis apicibus spathulatis (nec acutis neque brevitis acuminatis), foliis lobis calyculi supremi $0-2$ (nec 4-12) mm longis, floribus (4-)5-meris (nec 8-meris) et corolla 4.5-6(-10) (nec 12-15) mm 
longa differt. - Typus: Sonké \& Djuikouo 4188 (holo K; iso BR, BRLU, MO, WAG,

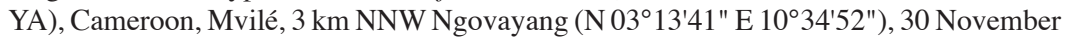
2005.

Small treelet, single stemmed, $0.5-2.5 \mathrm{~m}$ tall; main stem 2-9 mm diam., bark brown, smooth; branches usually whitish and soft-corky when dry, branchlets similar to the branches, usually peeling and then dark brown to blackish underneath and at uppermost parts (when dry). Stipules connate and surrounding branchlet at base, at least when young, limb ovate-triangular to depressed ovate, $2-4$ by $1-3 \mathrm{~mm}$, outside surface puberulous; apex shortly apiculate, apiculum $0.4-0.6 \mathrm{~mm}$ long. Leaves: petiole (2-)4-7(-8) mm long; leaf blades elliptic to elliptic-oblong, (8.5-)11-17 by $2.5-5.7$ $\mathrm{cm}$, apex spathulate, (8-)10-16 mm long, base cuneate, leaf surface glabrous above and below; secondary nerves prominent, 7-9 on each side of the midrib, ascending, straight to curved, joining to form a hooped intramarginal nerve; midrib prominent below, less prominent above; tertiary veins manifest, reticulate; domatia absent. Inflorescences axillary, paired and opposite, borne slightly above each axil (supra-axillary), sessile, 1- or 2-flowered, glabrous. Calyculi 2, the uppermost the largest, each calyculus 4-lobed ( 2 foliar lobes and 2 stipular lobes), \pm sessile, glabrous but beset with numerous colleters inside, and with several colleters on the margins; basal (1st) calyculus $0.5-1$ by $1-1.5 \mathrm{~mm}$, foliar lobes depressed ovate, c. $0.2 \mathrm{~mm}$ long, stipular lobes \pm triangular, $0.2-0.3 \mathrm{~mm}$ long; upper (2nd) calyculus $0.7-1$ by $1.5-2 \mathrm{~mm}$, foliar lobes very depressed ovate or \pm truncate, $0-0.2 \mathrm{~mm}$ long, stipular lobes \pm triangular, 0.2-0.4 mm long. Flowers hermaphrodite, homostylous, (4- or) 5-merous, sessile. Calyx (hypanthium) $0.5-1 \mathrm{~mm}$ long, glabrous; calyx limb truncate or very weakly and unevenly 5-lobed, glabrous, lacking colleters inside. Corolla funnel-shaped at maturity, glabrous, white; corolla lobes contorted to the left in bud; corolla tube cylindrical, widening slightly towards the apex, 4.5-6(-10) $\mathrm{mm}$ long; corolla lobes (2.5-)7-8 mm long, apices acute to shortly apiculate. Anthers fixed above the corolla tube at the base of the lobes, exserted, submedifixed; filaments (0.1-) $0.2-0.3 \mathrm{~mm}$ long; anther sacs very narrowly ovoid, $2.5-3 \mathrm{~mm}$ long, base rounded, apex subacute. Disc very short, \pm cylindrical, flat-topped, glabrous. Ovary \pm ovoid to ovoid-spherical, c. 0.5 by $1 \mathrm{~mm}$ (at flowering stage), bilocular, placentation axile, placenta fixed \pm at the mid point, each locule containing a single ovule, radicle oriented downwards (radicle inferior); style filiform but thickening towards apex, 6-8 $\mathrm{mm}$ long, glabrous; stigma exserted, bilobed, rather fleshy. Fruits berry-like, obovoid, $12-15$ by $5-10 \mathrm{~mm}$, yellow at maturity, glabrous. Seeds 2 , each seed lacking a readily discernible seed coat, \pm elliptic in outline, \pm semi-circular in cross section, $8.7-9.4$ by $6-6.8 \mathrm{~mm}$, surface smooth; endosperm entire, whitish.

Distribution - Argocoffeopsis spathulata is restricted to the region of South Cameroon.

Habitat \& Ecology - Argocoffeopsis spathulata occurs in closed-canopy evergreen forest with many epiphytes and a rich herb layer, classified by Letouzey (1985) as Biafran evergreen forests, rich in Caesalpiniaceae (Caesalpinioideae). This forest has a well-defined structure with a high degree of local endemism (e.g. Nguembou et al. 2006, Sonké et al. 2006). The area lies at 500-600 m above sea level.

Phenology - Flowering and fruiting in January, September, and November. 


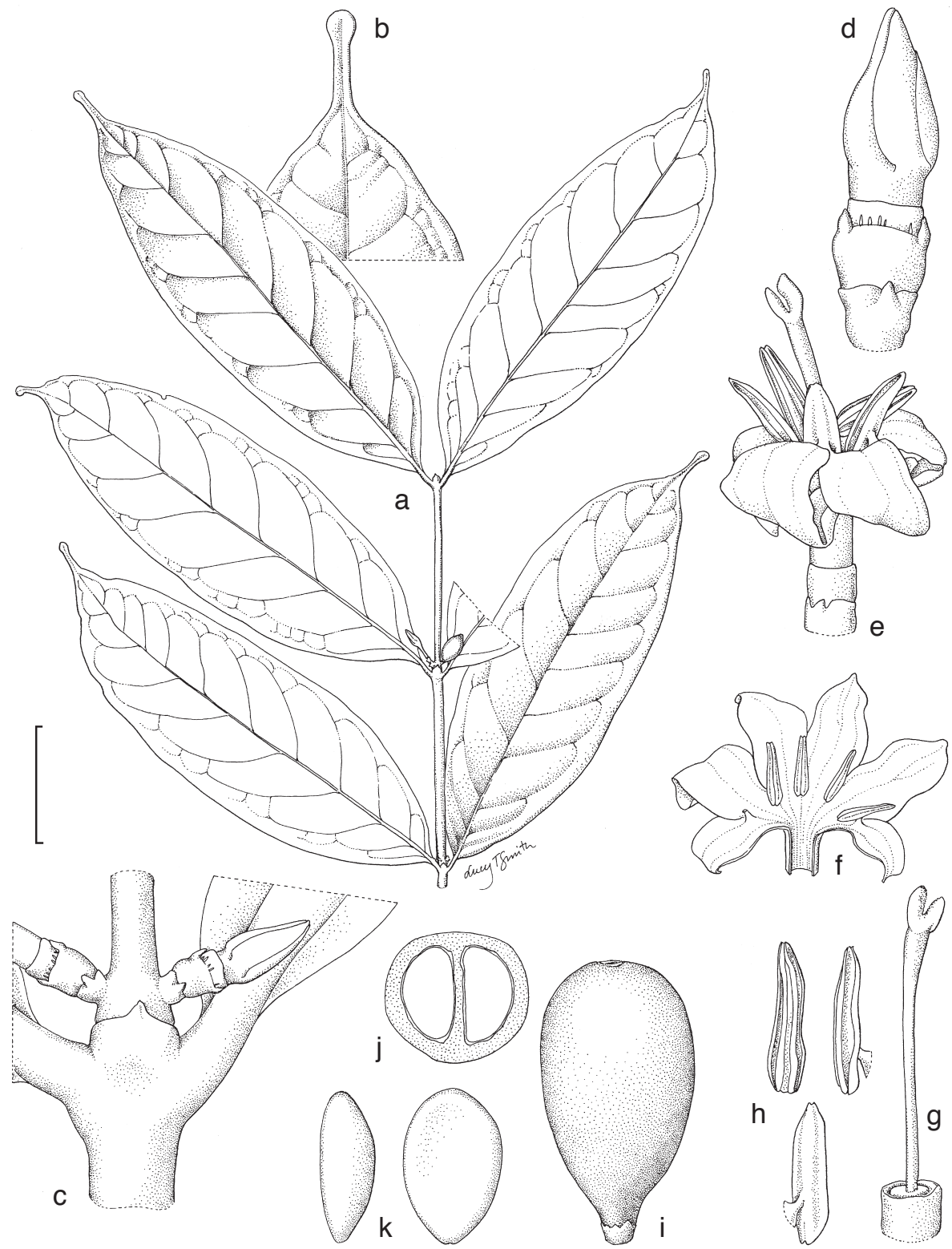

Fig. 1. Argocoffeopsis spathulata A.P.Davis \& Sonké. a. Habit; b. leaf apex; c. shoot section showing stipule, petioles and leaf bases, and opposed inflorescences; d. flower bud and calyculi; e. flower; f. corolla cut and opened out, with one anther removed; g. style and calyx limb; h. anther: front, side and rear views; i. fruit; j. fruit in transverse section; $k$. seeds: side and adaxial views. - Scale bar: $\mathrm{a}=4 \mathrm{~cm}, \mathrm{~b}=1.5 \mathrm{~cm}, \mathrm{c}, \mathrm{e}=5 \mathrm{~mm}, \mathrm{~d}=2.2 \mathrm{~mm}, \mathrm{f}=7 \mathrm{~mm}, \mathrm{~g}=4 \mathrm{~mm}, \mathrm{~h}=2.5 \mathrm{~mm}, \mathrm{i}-\mathrm{k}=1 \mathrm{~cm}(\mathrm{a}, \mathrm{b}$ : Sonké \& Djuikouo 4188; c, d: Sonké \& Nguembou 3873; e-h: Sonké \& Djuikouo 4060; i-k: Sonké \& Djuikouo 4250; all from K). Drawn by Lucy T. Smith. 


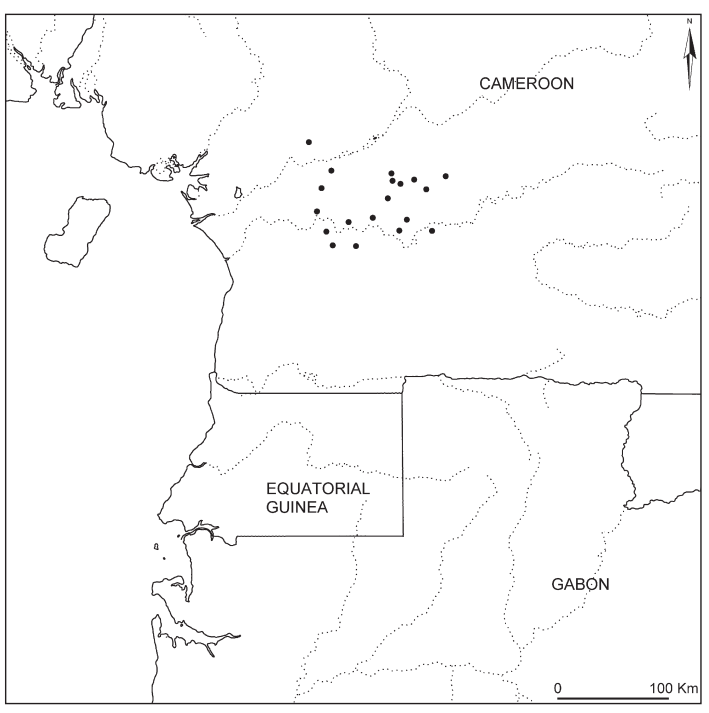

Map. 1. Distribution of Argocoffeopsis spathulata A.P.Davis \& Sonké.

Conservation status - IUCN Red List Category (IUCN 2001): Vulnerable (VU B1ab (i, ii, iii). B1 - extent of occurrence less than $20,000 \mathrm{~km}^{2}\left(8105 \mathrm{~km}^{2}\right.$ for A. spathulata); a - severely fragmented; b (i, ii, iii) - continuing decline inferred or projected for: i) extent of occurrence; ii) area of occupancy; and iii) quality of habitat. Other information: number of collections 21, consisting of 19 localities; area of occurrence 2929.5 $\mathrm{km}^{2}$ based on 19 cells of $12.4 \mathrm{~km}^{2}$.

Specimens examined:

SOUTH CAMEROON: Sonké \& Nguembou 3783 (BR, BRLU, K, MO, YA), Bibondi (N 03¹9'16" E 10³8'45") 24 Jan. 2005; Sonké \& Nguembou 3802 (BR, K, YA) and Sonké \& Nguembou 3813 (BR, K, YA), Bibondi (N 03²0'13" E 10³8'16") 25 Jan. 2005; Sonké \& Nguembou 3815 (BR, BRLU, K, MO, WAG, YA), Bibondi (N 03²1'08" E 10³8'05") 26 Jan. 2005; Sonké \& Nguembou 3864 (BR, BRLU, K, MO, WAG, YA), Bibondi (N 03¹8'11" E 10³8'57") 29 Jan. 2005; Sonké \& Nguembou 3873 (BR, BRLU, K, MO, WAG, YA), Ngoyang (N 03²1'28" E 1043'49") 15 Sept. 2005; Sonké \& Nguembou 3907 (BR, BRLU, K, MO, WAG, YA), Ngoyang (N 03²1'36" E 1044'31") 15 Sept. 2005; Sonké \& Nguembou 3968 (BR, BRLU, K, MO, WAG, YA), 3 km W Ngoyang (N 03²0'39" E 1044'02") 17 Sept. 2005; Sonké \& Nguembou 3997 (BR, BRLU, K, MO, WAG, YA), W Ngoyang (N 03²1'01" E 1043'15") 18 Sept. 2005; Sonké \& Nguembou 4015 (BR, K, MO, YA), W Ngoyang (N 03²1'01" E 1043'15") 18 Sept. 2005; Sonké \& Nguembou 4024 (BR, K, MO, YA), 3 km WNW Ngoyang (N 03²2'34" E 1043'59") 20 Sept. 2005; Sonké \& Djuikouo 4060 (BR, BRLU, K, MO, WAG, YA), Mvilé (Ngovayang) (N 03¹3'59" E 10³5'00") 25 Nov. 2005, Sonké \& Djuikouo 4060 (BR, BRLU, K, MO, WAG, YA); Sonké \& Djuikouo 4093 (BR, BRLU, K, MO, WAG, YA), 4 km WNW Ngovayang (N 03¹4'15" E 10³4'45") 26 Nov. 2005; Sonké \& Djuikouo 4117 (BR, K, MO, YA), Mvilé (Ngovayang) (N 03¹4'25" E 10³5'04") 27 Nov. 2005; Sonké \& Djuikouo 4152 (BR, K, MO, YA), Mvilé (3 km WNW Ngovayang) (N 03¹3'41" E 10³4'42") 28 Nov. 2005; Sonké \& Djuikouo 4188 (BR, BRLU, K, MO, WAG, YA), Mvilé, 3 km NNW Ngovayang (N 0313'41" E 10³4'52") 30 Nov. 2005; Sonké \& Djuikouo 4250 (BR, BRLU, K, MO, WAG, YA), 2 km NW Mbikiliki (N 03¹1'41" E 10³2'47") 18 Jan. 2006; Sonké \& Djuikouo 4285 (BR, BRLU, K, MO, WAG, YA), 2 km NW Mbikiliki (N 03¹1'11" E 10³2'14") 19 Jan. 2006; Sonké \& Djuikouo 4306 (BR, BRLU, K, MO, YA), 3 km NW Mbikiliki (N 03¹1'39" E 10³2'09") 20 Jan. 2006; Sonké \& Djuikouo 4332 (K, MO, YA), 3 km NW of Mbikiliki (N 03¹1'24" E 10³1'35") 21 Jan. 2006; Sonké \& Taedoumg 4396 (BR, K, MO, YA), 2 km NW Bidjouka (N 038'37" E 10²8'45"), 14 June 2006. 


\section{ACKNOWLEDGEMENTS}

Fieldwork leading to the discovery of Argocoffeopsis spathulata was supported by the National Geographic Society, through its Committee for Research and Exploration (grant $\mathrm{N}^{\circ} 7711-04$ and grant $\mathrm{N}^{\circ}$ 8377-07) and the Conseil Interuniversitaire de la Communauté Française de Belgique (CIUF), through the project Etude et utilisation de la diversité végétale pour promouvoir sa gestion durable en République Centrafricaine, Guinée Equatoriale et Cameroun (DIVEAC). We are also grateful to Cameroon Biodiversity Conservation Society and to the late Dr. Guillaume Dzikouk for logistic support in Cameroon. At the Royal Botanic Gardens, Kew (K), the following staff members are gratefully acknowledged: Lucy Smith for preparing the line drawing, Maria Vorontsova for help with the Latin diagnosis, and Arnaud Mansat for producing the distribution map and conservation assessment. Bonaventure Sonké would also like to express his gratitude to: Prof. Jean Lejoly (Laboratoire de Botanique systématique et de Phytosociologie, Université Libre de Bruxelles) for the facilities offered at BRLU; the Global Biodiversity Information Facility (GBIF) under the Electronic Catalogue of Names of Known Organisms (ECAT) programme, for supporting a visit to K in 2005; and the Missouri Botanical Garden (MO) for various assistance.

\section{REFERENCES}

Bridson, D.M. \& B. Verdcourt. 2003. Rubiaceae. In: G.V. Pope (ed.), Flora Zambesiaca vol. 5, part 3, 379-720. Royal Botanic Gardens, Kew.

Chevalier, A. 1938. Sur quelques faux caféiers d'Afrique tropicale. Rev. Int. Bot. Appl. Agric. Trop. 18: $413-419$.

Davis, A.P., D.M. Bridson \& F. Rakotonasolo. 2005. A reexamination of Coffea subgenus Baracoffea and comments on the morphology and classification of Coffea and Psilanthus (RubiaceaeCoffeeae). In: R.C. Keating, V.C. Hollowell \& T. Croat (eds.), Festschrift for William G. D'Arcy: the legacy of a taxonomist: 398-420. Monographs in Systematic Botany 104. Missouri Botanical Garden Press, St. Louis, Missouri, USA.

Davis, A.P., M. Chester, O. Maurin \& M.F. Fay. 2007. Searching for relatives of Coffea (Rubiaceae, Ixoroideae): Circumscription and phylogeny of Coffeeae based on plastid sequence data and morphology. Amer. J. Bot. 94: 313-329.

Holmgren, P.K., N.H. Holmgren \& L.C. Barnett. 1990. Index Herbariorum. Part 1: The Herbaria of the World, 8th ed. Regnum Veg. 120. New York Botanical Garden, New York.

IUCN. 2001. IUCN Red List Categories and Criteria: Version 3.1. Prepared by the IUCN Species Survival Commission. IUCN, Gland, Switzerland \& Cambridge, United Kingdom.

Lebrun, J. 1941. Recherches morphologiques et systématiques sur les caféiers du Congo. Mém. Inst. Roy. Colon. Belge, Sect. Sci. Nat. (8o) 11, 3: 55.

Letouzey, R. 1985. Notice de la carte phytogéographique du Cameroun au 1:500,000. 4: 63-142. Domaine de la forêt dense humide toujours verte. Institut de la Recherche Agronomique (Herbier National), Yaoundé, and Institut de la Carte Internationale de la Végétation, Toulouse.

Nguembou, K.C., P. Esono, J.M. Onana \& B. Sonké. 2006. Un Bertiera (Rubiaceae) nouveau et hétérophylle du Cameroun et du Gabon. Syst. Geogr. Pl. 76: 211-216.

Robbrecht, E. 1981. Studies in tropical African Rubiaceae (II): 5. A survey of Argocoffeopsis. 6. A revision of Calycosiphonia. Bull. Jard. Bot. Belg. 51: 370.

Sonké, B., K.C. Nguembou \& A.P. Davis. 2006. A new dwarf Coffea (Rubiaceae) from southern Cameroon. Bot. J. Linn. Soc. 151: 425-430.

Willis, F., J. Moat \& A. Paton. 2003. Defining a role for herbarium data in Red List assessments: a case study of Plectranthus from eastern and southern tropical Africa. Biodivers. \& Conservation 12: 1537-1552. 